\title{
Characterization of Oxidized Ferritic Stainless Steel with Undulated Surfaces for Metallic Interconnects
}

\author{
Daniel R. MUMM ${ }^{1}$, Sungbo SHIM ${ }^{2}$, Hye Ryoung PARK ${ }^{3}$, Myoung Youp SONG 4 * \\ ${ }^{1}$ Department of Chemical Engineering and Materials Science, University of California Irvine, Irvine, CA 92697-2575, \\ USA \\ ${ }^{2}$ High Temperature Composites, Rolls-Royce Corporation, Huntington Beach, CA92648, USA \\ ${ }^{3}$ School of Applied Chemical Engineering, Chonnam National University, 300 Yongbong-dong Buk-gu Gwangju, 61186, \\ Republic of Korea \\ ${ }^{4}$ Division of Advanced Materials Engineering, Research Center of Advanced Materials Development, Engineering \\ Research Institute, Chonbuk National University, 567 Baekje-daero Deokjin-gu Jeonju, 54896, Republic of Korea
}

cross $^{\text {ref }}$ http://dx.doi.org/10.5755/j01.ms.22.4.13054

Received 02 September 2015; accepted 31 January 2016

\begin{abstract}
One of the candidates for metallic interconnects of solid oxide fuel cells is a ferritic stainless steel, Crofer22 APU. Ferritic stainless steel Crofer22 APU samples with different roughness were prepared by grinding with SiC grinding papers of various grits, and a polished Crofer22 APU sample was also prepared. The prepared samples were then thermally cycled. The variations of their oxidation behavior with surface roughness and the number of thermal cycles were investigated. After 120 thermal cycles (a total $3000 \mathrm{~h}$ of exposure at $800^{\circ} \mathrm{C}$ ), the polished Crofer22 APU had a relatively flat, continuous $\mathrm{Cr}_{2} \mathrm{O}_{3}$ layer (thickness, $\sim 1 \mu \mathrm{m}$ ), while the Crofer22 APU ground with 80 grit showed an undulating, continuous $\mathrm{Cr}_{2} \mathrm{O}_{3}$ layer (thickness, $\sim 2 \mu \mathrm{m}$ ). For the samples that were thermally cycled 4 times (at $800{ }^{\circ} \mathrm{C}$ for $100 \mathrm{~h}$ total), the area specific resistance (ASR) increased as grit number increased for all measured temperatures $\left(600-850^{\circ} \mathrm{C}\right)$. Generally, for the samples that were thermally cycled 20 times, the ASR decreased slowly as the grit number increased. For the samples thermally cycled 40 times, the ASR decreased in general at all the measuring temperatures as the number of grit increased, indicating that the polished Crofer22 APU is better than those with rougher surfaces for the application of Crofer22 APU to an interconnect of SOFC.

Keywords: fuel cells, oxidation, microstructure, X-ray diffraction, ferritic stainless steel interconnect.
\end{abstract}

\section{INTRODUCTION}

Materials for the interconnect of a solid oxide fuel cell (SOFC) [1-4] are required to have several excellent properties from the viewpoints of electronic conductivity and ionic conductivity, chemical stability in both fuel and air and with respect to other cell parts, thermal expansion match to other cell parts, strength and toughness, thermal conductivity, and ability to make gas-tight seals with other cell parts, and to be of low cost.

Metallic interconnects [5-10] can be used since the SOFC operating temperature reduced down from $900-1000{ }^{\circ} \mathrm{C}$ to $600-850{ }^{\circ} \mathrm{C}$ recently [11]. They are advantageous over ceramic interconnects, such as lanthanum chromite $\left(\mathrm{LaCrO}_{3}\right)$ [12], from the standpoints of material and fabrication costs, complex shaping, electrical and thermal conductivity, and deformation or failure for the difference in gas atmosphere across the interconnection. However, the metallic interconnects are oxidized under SOFC operation conditions, leading to the increase in contact resistance and thus the decrease in electrical conductivity.

Yang et al. [13] evaluated heat resistance alloys in order to apply them to SOFC interconnects. They reported that ferritic stainless steels with optimized compositions are the best candidates for SOFC interconnect materials and either surface or bulk needs to be modified in the

\footnotetext{
* Corresponding author. Tel.: +82-63-270-2379; fax: +82-63-270-2386

E-mail address: songmy@jbnu.ac.kr (M. Y. Song)
}

chromia-forming alloys. They also reported that alumina formers, with better surface stability than the chromiaforming compositions and higher mechanical strength, may be applied in non-conducting stack components.

How ferritic stainless steels were oxidized under the conditions of SOFC interconnect exposure was investigated by Yang et al. [14]. $\mathrm{Cr}_{2} \mathrm{O}_{3}$ and $\mathrm{M}_{3} \mathrm{O}_{4}(\mathrm{M}=\mathrm{Cr}$, $\mathrm{Mn}$, and/or Fe) spinel were formed in either side of the coupon exposed to air on both sides during heating, which was revealed by XRD analysis. Iron was rich in the spinel top layer of the scale on the air side of Crofer22 APU $(\sim 23 \% \mathrm{Cr})$ after an isothermal heating at $800{ }^{\circ} \mathrm{C}$, and the anomalous oxidation was accelerated by increasing both temperature and thermal cycling. In addition, they reported that, for the ferritic stainless steels with relatively low $\mathrm{Cr}$ content, the presence of hydrogen led to an enrichment of iron in the scale probably by accelerating the iron transport in the scale.

Among metallic interconnect candidates, a new ferritic stainless steel, Crofer22 APU, is an alloy prepared by modifying bulk to improve both oxidation/corrosion resistance and scale conductivity. Crofer22 APU was developed by Forschungszentrum Julich of Germany, and consists of $\sim 23$ wt.\% $\mathrm{Cr}$ and small quantities of $\mathrm{Mn}, \mathrm{Ni}$, $\mathrm{Al}, \mathrm{Si}, \mathrm{La}$, and Ti.

The formation of an oxide layer on different metallic samples (i.e., Crofer22 APU, SS430 and Conicro 4023 W188) treated at $800{ }^{\circ} \mathrm{C}$ for 100 and $1000 \mathrm{~h}$ in air was investigated by Miguel-Pérez et al. [15]. The oxide scale 
formed on the metallic interconnect consists of a spinel ( $\mathrm{Fe}$, $\mathrm{Cr}, \mathrm{Mn})_{3} \mathrm{O}_{4}$ or $(\mathrm{Fe}, \mathrm{Cr}, \mathrm{Ni})_{3} \mathrm{Co}_{2} \mathrm{O}_{4}$ outer layer and a chromia $\left(\mathrm{Cr}_{2} \mathrm{O}_{3}\right)$ inner layer. The Crofer22 APU and Conicro $4023 \mathrm{~W} 188$ samples were more promising as metallic interconnects than SS430 due to their higher oxidation resistance.

Magdefrau et al. [16] studied the effect of alloy heat treatment on the oxidation kinetics and oxide scale microstructure of Crofer22 APU. They reported that parabolic oxidation rate constants were measured for the as-received alloy and after pre-oxidation heat treatment in argon at $1050{ }^{\circ} \mathrm{C}$ for 1 and $4 \mathrm{~h}$. The alloy formed a twolayer scale with a continuous chromia layer and a discontinuous $\mathrm{MnCr}_{2} \mathrm{O}_{4}$ overlayer. The heat-treated samples exhibit a 3.5 times lower parabolic oxidation rate constant than the as-received Crofer 22 APU.

In addition to these researches, many works have been performed for Crofer22 APU [17-23]. However, a few researchers studied on the oxidation behaviour of this alloy with different roughness, as the number of thermal cycles increases.

In this work, Crofer22 APU samples with various roughness were prepared by grinding with $\mathrm{SiC}$ grinding papers of different grits $(80,120,240,400$, and 800), and a polished Crofer22 APU sample was also prepared. The prepared samples were then thermally cycled. The variations of their oxidation behavior with surface roughness and the number of thermal cycles were then investigated.

\section{EXPERIMENTAL}

A Crofer22 APU plate (a thickness of $0.8 \mathrm{~mm}$ ) was cut into $1 \times 1 \mathrm{~cm}$ squares and ground with grinding papers of different grits. The chemical composition of Crofer22 APU [24] is given in Table 1.

Table 1. Chemical composition of Crofer22 APU used in the experiment

\begin{tabular}{|c|c|c|c|c|c|c|c|c|c|}
\hline & $\mathrm{Cr}$ & $\mathrm{Mn}$ & $\mathrm{Al}$ & $\mathrm{Si}$ & $\mathrm{Ni}$ & $\mathrm{Ti}$ & $\mathrm{V}$ & $\mathrm{Co}$ & Others \\
\hline Crofer22APU & 23 & 0.41 & 0.12 & 0.1 & 0.16 & 0.05 & - & - & $0.08 \mathrm{La}$ \\
\hline
\end{tabular}
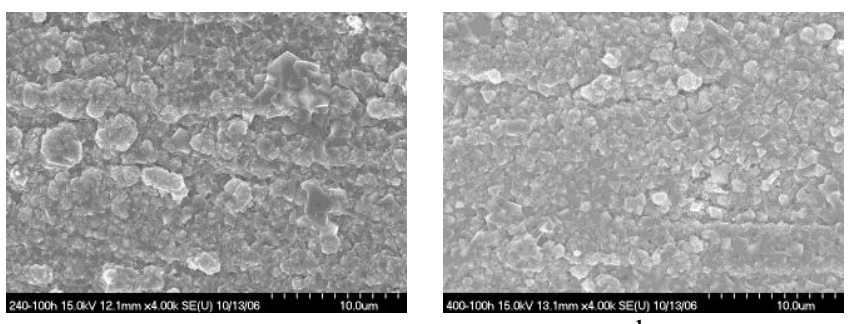

b
Samples with six different roughness were prepared by grinding with $80,120,240,400$, and 800 grit SiC grinding papers (emery papers) and by polishing. The samples were cycled by heating to $800{ }^{\circ} \mathrm{C}$ with a heating rate of $10{ }^{\circ} \mathrm{C} / \mathrm{min}$, maintaining at $800{ }^{\circ} \mathrm{C}$ for $25 \mathrm{~h}$, and cooling to room temperature with a cooling rate of $10^{\circ} \mathrm{C} / \mathrm{min}$. The numbers of thermal cycles (n) for the preparation of samples were $4,8,20,30,40$, and 120 , with the $800^{\circ} \mathrm{C}$ maintenance periods (oxidation time) being 100, 200, 500, 750,1000 , and $3000 \mathrm{~h}$, respectively.

The surfaces of the prepared samples were investigated by cold field-emission scanning electron microscopy (FE-SEM) and energy dispersive X-ray spectrometry (EDX, S-4700, Hitachi, Japan). With an Xray diffractometer (XRD, Rigaku D/MAX Ultima III), Xray diffraction patterns were obtained using $\mathrm{Cu} \mathrm{K} \alpha$ radiation at a scanning rate of $2 \% \mathrm{~min}$. The scanned range of the diffraction angle $(2 \theta)$ was $5^{\circ} \leq 2 \theta \leq 80^{\circ}$ [25]. A sample ground with grit 80 and another polished sample were oxidized for $3000 \mathrm{~h}(\mathrm{n}=120)$, and micro-structural observation and phase identification by SEM of their scale/alloy interfaces milled by FIB (focused ion beam) were performed.

Electrical resistance of the cycled samples was measured by a four-probe DC technique using 2400 sourcemeter and 2182 nanovoltmeter, Keithley Instruments [26-28]. A perovskite $\mathrm{LaNi}_{0.6} \mathrm{Fe}_{0.4} \mathrm{O}_{3}$ (LNF) paste was applied on the cycled Crofer22 APU sheet to form $1 \mathrm{~cm}^{2}$ electrode. Two Pt electrical leads were spot-welded to the edge of each sheet. Parameters of power and time for spot welding were optimized to ensure the formation of metallurgical bond. The sample assembly was inserted to the furnace, and heated to $600{ }^{\circ} \mathrm{C}$ for the ASR measurement. ASR measurements were also performed at $650,700,750,800$, and $850{ }^{\circ} \mathrm{C}$. A thermal gradient between the sample and the voltmeter is unavoidable. A thermoelectric electron magnetic frequency (EMF) is created by this thermal gradient.

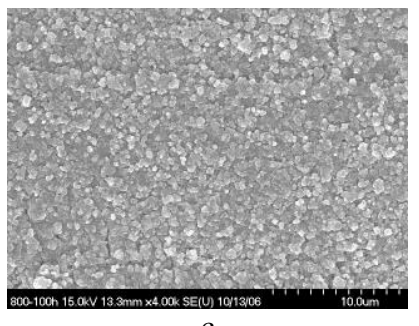

$\mathrm{c}$

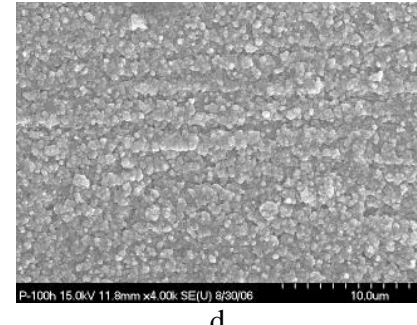

d

Fig. 1. SEM images for the surfaces of the Crofer22 APU samples ground with: a-grit 240; b-grit 400; $\mathrm{c}-$ grit 800; d-polished Crofer22 APU sample, after 4 thermal cycles

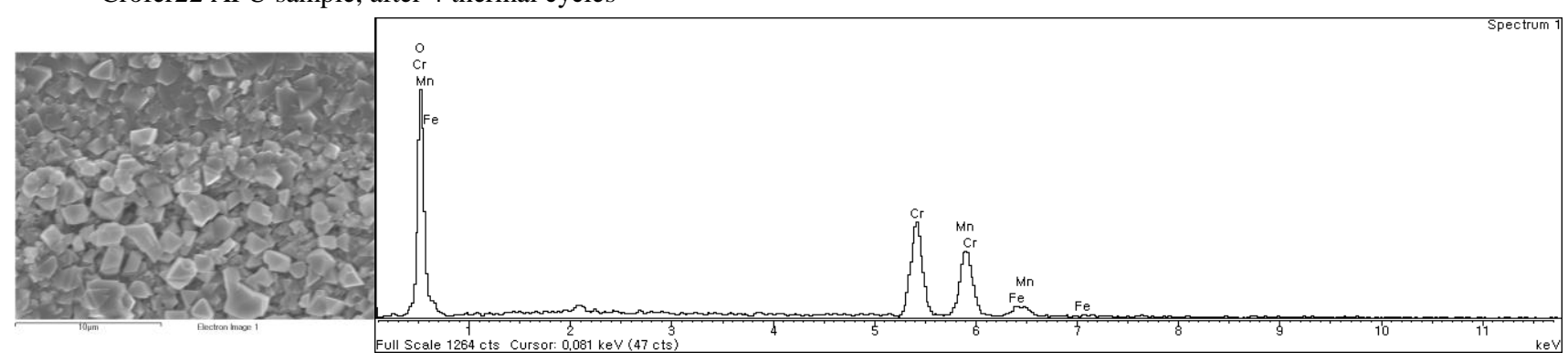

Fig. 2. SEM image and EDX spectrum of the Crofer22 APU sample ground with 120 grit after $n=20$ 
The thermoelectric EMF decreases the accuracy of low resistance measurements. In order to eliminate errors induced from the thermoelectric EMF, used were the current reversal technique, which measures the induced voltage in both current directions, then computes the corresponding resistance for each direction, and finally averages the two measured values.

\section{RESULTS AND DISCUSSION}

Fig. 1 presents SEM images for the surfaces of the Crofer22 APU samples ground with 240, 400, and 800 grit and the polished Crofer22 APU sample, after 4 thermal cycles. The oxide grains are in the form of round scale. As the grit number increases, the grains become smaller. Ridges made by grinding with a $\mathrm{SiC}$ grinding paper (an emery paper) do not appear clearly, but the polished sample shows quite clear ridges in the direction of grinding with an emery paper. The particles of an emery paper with a larger grit number are smaller than those of an emery paper with a smaller grit number. When samples are ground with an emery paper with a larger grit number, the ridges formed on the surface of samples are lower than those formed on the surface of samples ground with an emery paper with a smaller grit number. Samples ground with an emery paper with a larger grit number have a larger density of defects than those ground with an emery paper with a smaller grit number. These defects are believed to act as active sites for the nucleation of oxides. A larger density of the active sites for the nucleation will lead to a larger content of nuclei. Growth of the larger number of nuclei in a unit volume will lead to smaller grains in the samples ground with an emery paper with a larger grit number.

A SEM image and an EDX spectrum of the Crofer22 APU sample ground with 120 grit after $n=20$ are shown in Fig. 2. The ridges made by grinding with the emery paper do not appear clearly. The EDX spectrum shows that the surface of this sample contains $\mathrm{O}, \mathrm{Cr}, \mathrm{Mn}$, and $\mathrm{Fe}$. Table 2 shows the EDX result for the Crofer22 APU ground with 120 grit after $\mathrm{n}=20$. The atomic percentages of the elements $\mathrm{O}, \mathrm{Cr}, \mathrm{Mn}$, and $\mathrm{Fe}$ are 56.02, 23.49, 17.87 and 2.62 , respectively. The atomic percentages of the elements $\mathrm{O}, \mathrm{Cr}$, and $\mathrm{Mn}$ show ones approaching the composition of $(\mathrm{Cr}, \mathrm{Mn}){ }_{3} \mathrm{O}_{4}$ spinel phase.

Table 2. EDX result for the Crofer22APU ground with 120 grit after $\mathrm{n}=20$

\begin{tabular}{|c|c|c|}
\hline Element & Weight \% & Atomic \% \\
\hline $\mathrm{O}$ & 27.61 & 56.02 \\
\hline $\mathrm{Cr}$ & 37.63 & 23.49 \\
\hline $\mathrm{Mn}$ & 30.24 & 18.87 \\
\hline $\mathrm{Fe}$ & 4.51 & 2.62 \\
\hline Total & 100.00 & 100.00 \\
\hline
\end{tabular}

XRD patterns of the Crofer22 APU samples of 400 grit after 4, 8, 20,30, and 40 thermal cycles are shown in Fig. 3. These samples exhibit $\mathrm{Cr}_{2} \mathrm{O}_{3},(\mathrm{Cr}, \mathrm{Mn})_{3} \mathrm{O}_{4}$ spinel, and alloy substrate phases. As the number of thermal cycles increases, the content of the $(\mathrm{Cr}, \mathrm{Mn})_{3} \mathrm{O}_{4}$ spinel phase increases and that of the alloy substrate phase decreases, whereas the content of $\mathrm{Cr}_{2} \mathrm{O}_{3}$ phase remains almost constant. This shows that the $(\mathrm{Cr}, \mathrm{Mn})_{3} \mathrm{O}_{4}$ spinel phase grows on the surface of the polished Crofer22 APU samples.

Fig. 4 presents SEM images of trenches milled utilizing the FIB on the oxides grown on a polished Crofer22 APU sample and a Crofer22 APU sample ground with 80 grit after 120 thermal cycles (a totally $3000 \mathrm{~h}$ of exposure at $800{ }^{\circ} \mathrm{C}$ ), which exhibits key microstructural development features. The trenches exhibit an alloy substrate phase, a $\mathrm{Cr}_{2} \mathrm{O}_{3}$ layer, and a $(\mathrm{Cr}, \mathrm{Mn})_{3} \mathrm{O}_{4}$ spinel phase on the surface. The polished sample has a relatively flat continuous $\mathrm{Cr}_{2} \mathrm{O}_{3}$ layer with a thickness of about $1 \mu \mathrm{m}$, while the sample ground with 80 grit shows an undulating $\mathrm{Cr}_{2} \mathrm{O}_{3}$ layer with a thickness of about $2 \mu \mathrm{m}$.

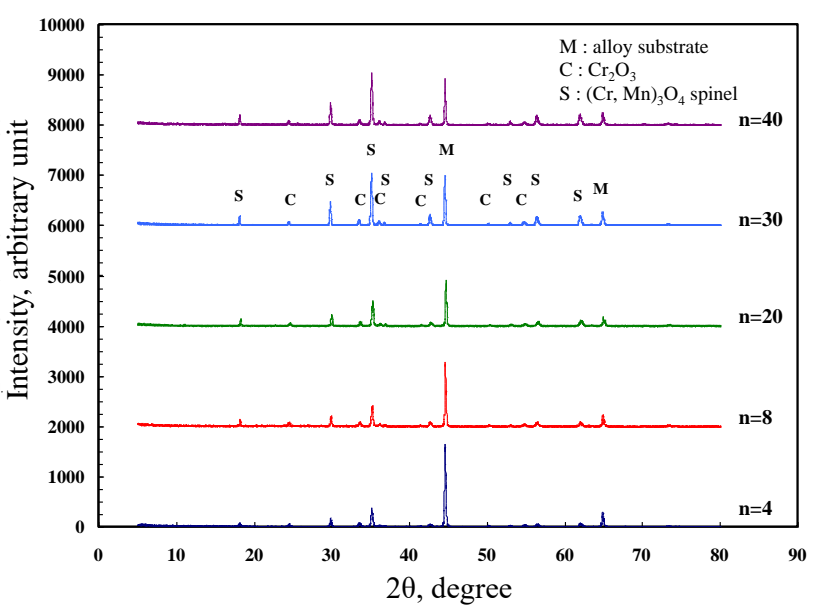

Fig. 3. XRD patterns of the Crofer 22 APU samples of 400 grit after $4,8,20,30$, and 40 thermal cycles

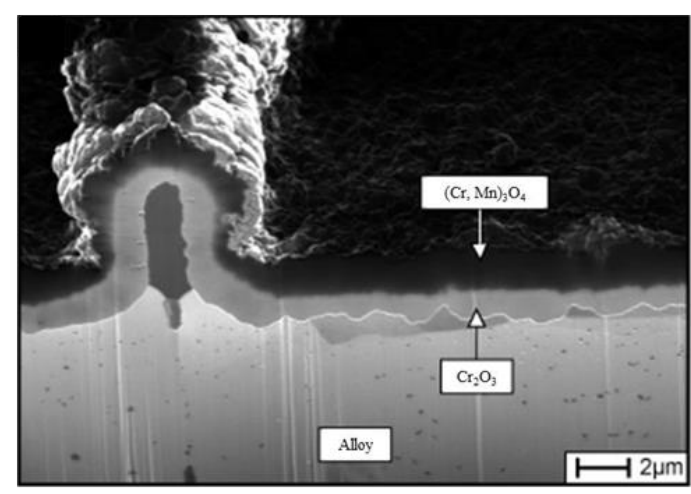

a

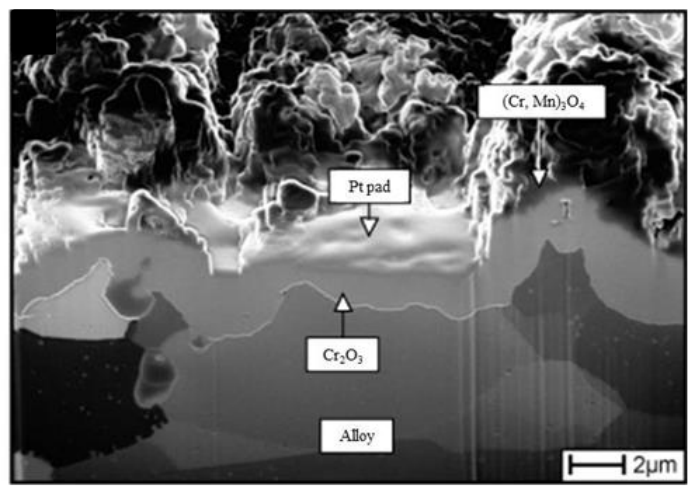

$\mathrm{b}$

Fig. 4. SEM images of the focused ion milled region of the oxide/alloy interface for: a-a polished Crofer22 APU sample; $b$-a Crofer22 APU sample ground with 80 grit after 120 thermal cycles 
Variations in area specific resistance (ASR) with the number of cycles for the samples ground with 400 grit at different measuring temperatures were investigated. ASR increased as the number of cycles increased. The ASRs of the sample ground with 400 grit, measured at $800{ }^{\circ} \mathrm{C}$, were $4.8 \mathrm{mohm} \mathrm{\textrm {cm } ^ { 2 }}$ after $\mathrm{n}=4$, and $10.6 \mathrm{mohm} \mathrm{cm}^{2}$ after $\mathrm{n}=40$. Fig. 4 shows that the oxidized Crofer22 APU contains $\mathrm{Cr}_{2} \mathrm{O}_{3}$ and $(\mathrm{Cr}, \mathrm{Mn})_{3} \mathrm{O}_{4}$ spinel phases. It is known that a small amount of $\mathrm{SiO}_{2}$ also forms in the interior of the Crofer22 APU sample after oxidation treatment [26]. The increase in the ASR with thermal cycling is considered to be due to the formation of these oxides.

Fig. 5 shows the variations in ASR with the grit number for the samples thermally cycled 4 times, with an $800{ }^{\circ} \mathrm{C}$ maintenance period of $100 \mathrm{~h}$.
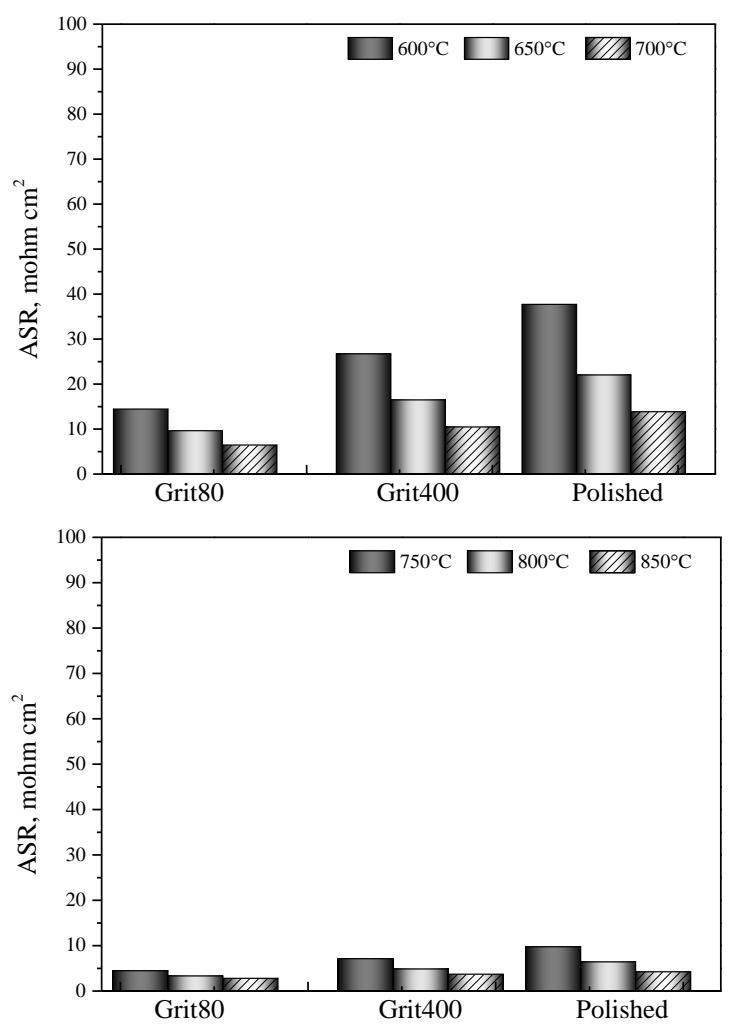

Fig. 5. Variations in ASR with the grit number at different measuring temperatures for the samples thermally cycled 4 times

The ASR was measured at temperatures of 600, 650, $700,750,800$, and $850{ }^{\circ} \mathrm{C}$. At all measuring temperatures, the ASR increases as the grit number increases from 80 to 400, and the ASR increases more rapidly as the grit number increases from 400 grit to the polished sample. The ASRs of the sample ground with 80 grit and of the polished sample, both measured at $800{ }^{\circ} \mathrm{C}$, are 3.3 and $6.9 \mathrm{mohm} \mathrm{cm} \mathrm{c}^{2}$, respectively, after $\mathrm{n}=4$. At thermally cycled 4 times samples, the samples ground with larger grit numbers, than those ground with smaller grit numbers, are believed to have a larger defect density and thus more active sites for nucleation in a unit volume, leading to high oxidation rates and larger values of ASR.

The variations in ASR as a function of grit number for samples with $\mathrm{n}=20$ and the $800{ }^{\circ} \mathrm{C}$ maintenance period of $500 \mathrm{~h}$ are presented in Fig. 6. At some measuring temperatures the ASR increases as the grit number increases.
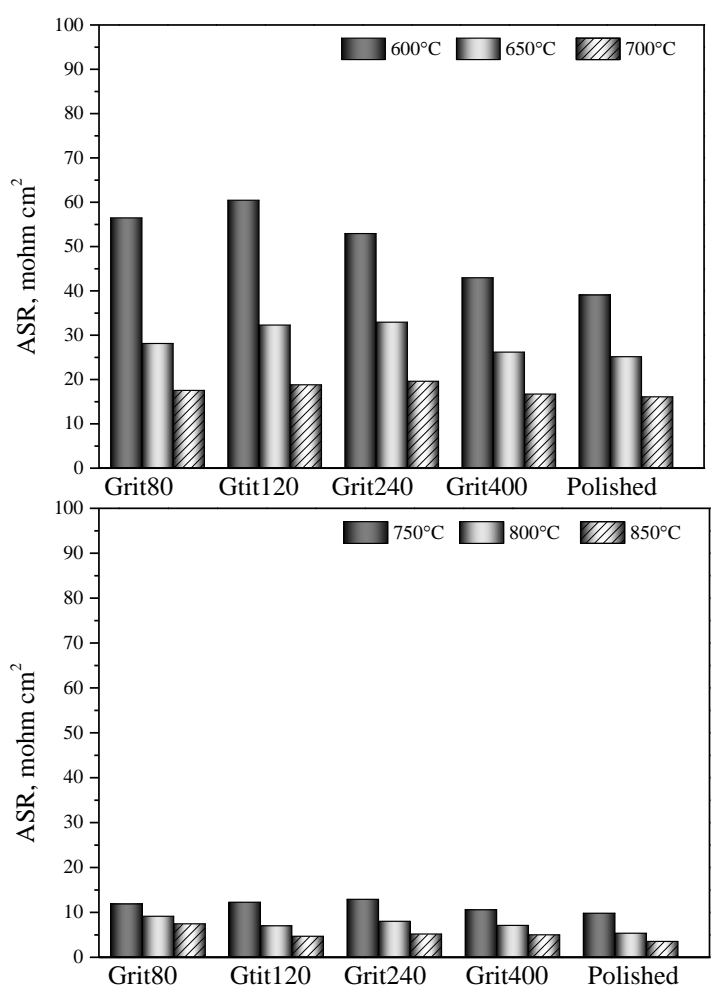

Fig. 6. Variations in ASR with the grit number at different measuring temperatures for the samples thermally cycled 20 times

At other measuring temperatures the ASR decreases as the grit number increases. A monotonic and clear trend of ASR with grit number is not observed for all the different measuring temperatures. Roughly speaking, the ASR decreases slowly as the grit number increases. The ASRs of the sample ground with 80 grit and of the polished

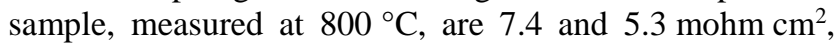
respectively, after $\mathrm{n}=20$.

Fig. 7 shows the variations in ASR with the grit number for the samples thermally cycled 40 times, with the $800{ }^{\circ} \mathrm{C}$ maintenance period of $1000 \mathrm{~h}$.

At all measuring temperatures, the ASR decreases, in general, as the grit number increases. The ASRs of the sample ground with 80 grit and the polished sample, measured at $800{ }^{\circ} \mathrm{C}$, are 14.9 and $10.2 \mathrm{mohm} \mathrm{cm}^{2}$, respectively, after $n=40$. Fig. 4 shows that the polished sample after 120 thermal cycles has a relatively flat, continuous $\mathrm{Cr}_{2} \mathrm{O}_{3}$ layer with a thickness of $\sim 1 \mu \mathrm{m}$, while the sample ground with 80 grit displays an undulating, continuous $\mathrm{Cr}_{2} \mathrm{O}_{3}$ layer with a thickness of $\sim 2 \mu \mathrm{m}$. The larger thickness of the $\mathrm{Cr}_{2} \mathrm{O}_{3}$ layer in the sample ground with 80 grit than that in the polished sample supports the fact that the former has a larger ASR value than the latter. It is reported that Crofer22 APU is protected at elevated temperatures via formation of a unique scale comprised of a $(\mathrm{Cr}, \mathrm{Mn})_{3} \mathrm{O}_{4}$ spinel top layer and a chromia sub-layer [29]. It is considered that a flat continuous $\mathrm{Cr}_{2} \mathrm{O}_{3}$ layer is more impermeable to oxygen than an undulating continuous $\mathrm{Cr}_{2} \mathrm{O}_{3}$ layer since the flat $\mathrm{Cr}_{2} \mathrm{O}_{3}$ layer has less passage such as crack for oxygen than the undulating continuous $\mathrm{Cr}_{2} \mathrm{O}_{3}$ layer. The impermeability to oxygen of the relatively flat continuous $\mathrm{Cr}_{2} \mathrm{O}_{3}$ layer from the polished 
Crofer22 APU is considered to lead to the thinner $\mathrm{Cr}_{2} \mathrm{O}_{3}$ layer and the lower ASR value of the polished sample than the sample ground with 80 grit. In a similar way, the ASR is considered to decrease as the grit number increases. This indicates that the polished Crofer22 APU is better than those with rougher surfaces for the application of Crofer22 APU to an interconnect of SOFC.
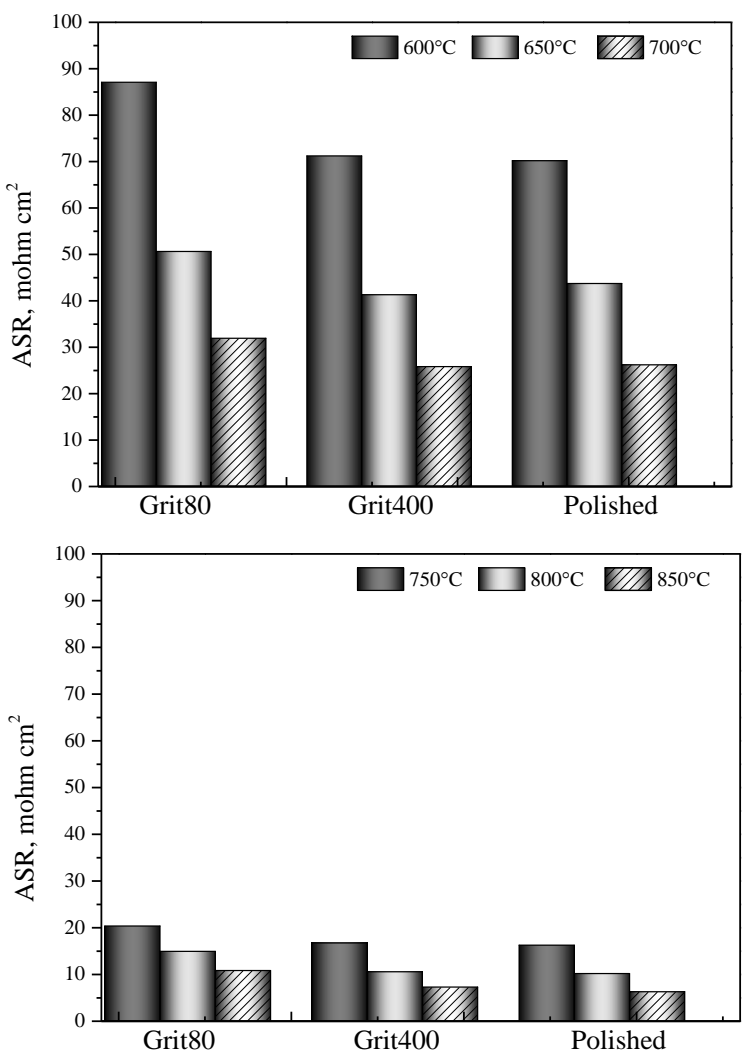

Fig. 7. Variations in ASR with the grit number at different measuring temperatures for the samples thermally cycled 40 times

\section{CONCLUSIONS}

The trenches of Crofer22 APU after 120 thermal cycles (a total of $3000 \mathrm{~h}$ exposure at $800^{\circ} \mathrm{C}$ ), prepared by utilizing the FIB, exhibit an alloy substrate phase, a $\mathrm{Cr}_{2} \mathrm{O}_{3}$ layer, and a $(\mathrm{Cr}, \mathrm{Mn})_{3} \mathrm{O}_{4}$ spinel phase on the surface. The polished sample had a relatively flat, continuous $\mathrm{Cr}_{2} \mathrm{O}_{3}$ layer with a thickness of $\sim 1 \mu \mathrm{m}$, while the sample ground with 80 grit showed an undulating $\mathrm{Cr}_{2} \mathrm{O}_{3}$ layer with a thickness of $\sim 2 \mu \mathrm{m}$. For the samples thermally cycled 4 times with an $800{ }^{\circ} \mathrm{C}$ maintenance period of $100 \mathrm{~h}$, the ASR increased as the grit number increased at the all the measuring temperatures $\left(600-850^{\circ} \mathrm{C}\right)$. For the samples of $\mathrm{n}=20$, a monotonic and clear trend of ASR with the grit number was not observed at any of the measuring temperatures. Generally, the ASR decreased slowly as the grit number increased. For samples thermally cycled 40 times, the ASR decreased at all the measuring temperatures, in general, as the grit number increased. The larger impermeability to oxygen of the flatter continuous $\mathrm{Cr}_{2} \mathrm{O}_{3}$ layer of the samples ground with the larger grit number, compared with the samples ground with the smaller grit number, is considered to lead to the lower value of ASR of the former. This indicates that the polished Crofer22 APU is better than those with rougher surfaces for the application of Crofer22 APU to an interconnect of SOFC.

\section{REFERENCES}

1. Kang, Y.J., Jung, S.H., An, Y.T., Choi, B.H., Ji, M.J. Electrical Conductivity of Ni-YSZ Anode for SOFCs according to the Ni Powder Size Variations in Core-shell Structure Korean Journal of Metals and Materials 53 (4) 2015: pp. 287-293.

2. Seo, S.W., Jung, S.J., Park, M.W., Yu, S.M., Lee, K.T., Lee, J.S. Effects of Strontium Gallate Addition on Sintering Behavior and Electrical Conductivity of Yttria-doped Ceria Electronic Materials Letters 10 (1) 2014: pp. 213-216.

3. Seo, S.W., Park, J.H., Park, M.W., Koo, J.H., Lee, K.T., Lee, J.S. Effects of Gallia Addition on Sintering Behavior and Electrical Conductivity of Yttria-doped Ceria Electronic Materials Letters 10 (1) 2014: pp. 791-794.

4. Kim, H.K., Lee, S.H., Lee, S.G., Lee, Y.H. Densification Mechanism of $\mathrm{BaTiO}_{3}$ Films on Cu Substrates Fabricated by Aerosol Deposition Electronic Materials Letters 11 (3) 2015: pp. $388-397$.

5. Chen, L., Yang, Z., Jha, B., Xia, G., Stevenson, J.W. Clad Metals, Roll Bonding and Their Applications for SOFC Interconnects Journal of Power Sources 152 2005: pp. $40-45$. http://dx.doi.org/10.1016/j.jpowsour.2005.01.055

6. Linder, M., Hocker, T., Holzer, L., Pecho, O., Andreas Friedrich, A., Morawietz, T., Hiesgen, R., Kontic, R., Iwanschitz, B., Mai, A., Andreas Schuler, J. Ohmic Resistance of Nickel Infiltrated Chromium Oxide Scales in Solid Oxide Fuel Cell Metallic Interconnects Solid State Ionics 283 2015: pp. 38-51.

7. Magrasó, A., $\quad$ Falk-Windisch, H., $\quad$ Froitzheim, J., Svensson, J.-E., Haugsrud, R. Reduced Long Term Electrical Resistance in Ce/Co-coated Ferritic Stainless Steel for Solid Oxide Fuel Cell Metallic Interconnects International Journal of Hydrogen Energy 40 (27) 2015: pp. 8579-8585.

8. Lin, C.K., Liu, Y.A., Wu, S.H., Liu, C.K., Lee, R.Y. Joint Strength of a Solid Oxide Fuel Cell Glass-ceramic Sealant with Metallic Interconnect in a Reducing Environment Journal of Power Sources 280 2015: pp. 272-288.

9. Zhang, W., Yan, D., Yang, J., Chen, J., Chi, Bo., Pu, J., Li, J. A Novel Low Cr-containing $\mathrm{Fe}-\mathrm{Cr}-\mathrm{Co}$ Alloy for Metallic Interconnects in Planar Intermediate Temperature Solid Oxide Fuel Cells Journal of Power Sources 271 2014: pp. 25-31.

10. Wu, W., Guan, W., Wang, G., Liu, W., Zhang, Q., Chen, T., Wang, W.G. Evaluation of $\mathrm{Ni}_{80} \mathrm{Cr}_{20} /\left(\mathrm{La}_{0.75} \mathrm{Sr}_{0.25}\right)_{0.95} \mathrm{MnO}_{3}$ Dual Layer Coating on SUS 430 Stainless Steel Used as Metallic Interconnect for Solid Oxide Fuel Cells International Journal of Hydrogen Energy 39 (2) 2014: pp. 996-1004.

11. Park, C.H., Baik, K.H. Improvements in Oxidation Resistance and Conductivity of $\mathrm{Fe}-\mathrm{Cr}$ Metallic Interconnector by $\left(\mathrm{La}_{0.8} \mathrm{Ca}_{0.2}\right)\left(\mathrm{Cr}_{0.9} \mathrm{Co}_{0.1}\right) \mathrm{O}_{3}$ Coating Metals and Materials International 20 (1) 2014: pp. 63-67. http://dx.doi.org/10.1007/s12540-014-1005-1

12. Minh, N.Q. Ceramic Fuel Cells Journal of the American Ceramic Society 76 (3) 1993: pp. 563-588. http://dx.doi.org/10.1111/j.1151-2916.1993.tb03645.x

13. Yang, Z., Scott Weil, K., Paxton, D.M., Stevenson, J.W. Selection and Evaluation of Heat-resistant Alloys for SOFC 
Interconnect Applications Journal of the Electrochemical Society 150 (9) 2003: pp. A1188-1201.

http://dx.doi.org/10.1149/1.1595659

14. Yang, Z., Walker, M.S., Singh, P., Stevenson, J.W., Norby, T. Oxidation Behavior of Ferritic Stainless Steels under SOFC Interconnect Exposure Conditions Journal of the Electrochemical Society 151(12) 2004: pp. B669-678. http://dx.doi.org/10.1149/1.1810393

15. Miguel-Pérez, V., Martínez-Amesti, A., Nó, M.L., Larrañaga, A., Arriortua, M.I. The Effect of Doping (Mn, B) ${ }_{3} \mathrm{O}_{4}$ Materials as Protective Layers in Different Metallic Interconnects for Solid Oxide Fuel Cells Journal of Power Sources 243 2013: pp. 419-430.

16. Magdefrau, N.J., Chen, L., Sun, E.Y., Aindow, M. Effects of Alloy Heat Treatment on Oxidation Kinetics and Scale Morphology for Crofer22 APU Journal of Power Sources 241 2013: pp. 756-767. http://dx.doi.org/10.1016/j.jpowsour.2013.03.181

17. Yang, Z., Xia, G., Stevenson, J.W. $\mathrm{Mn}_{1.5} \mathrm{Co}_{1.5} \mathrm{O}_{4}$ Spinel Protection Layers on Ferritic Stainless Steels for SOFC Interconnect Applications Electrochemical and Solid-State Letters 8 (3) 2005: pp. A168-170. http://dx.doi.org/10.1149/1.1854122

18. Yang, Z., Xia, G., Simner, S.P., Stevenson, J.W. Thermal Growth and Performance of Manganese Cobaltite Spinel Protection Layers on Ferritic Stainless Steel SOFC Interconnects Journal of the Electrochemical Society 152 (9) 2005: pp. A1896-1901. http://dx.doi.org/10.1149/1.1990462

19. Yang, Z., Xia, G., Singh, P., Stevenson, J.W. Electrical Contacts between Cathodes and Metallic Interconnects in Solid Oxide Fuel Cells Journal of Power Sources 155 (2) 2006: pp. 246-252.

20. Chou, Y.S., Stevenson, J.W., Xia, G.G., Yang, Z.G. Electrical Stability of a Novel Sealing Glass with (Mn, Co)Spinel Coated Crofer22 APU in a Simulated SOFC Dual Environment Journal of Power Sources $195(17)$ 2010: pp. $5666-5673$. http://dx.doi.org/10.1016/j.jpowsour.2010.03.052
21. Fu, Q.X., Sebold, D., Tietz, F., Buchkremer, H.P. Electrodeposited Cobalt Coating on Crofer22 APU Steels for Interconnect Applications in Solid Oxide Fuel Cells Solid State Ionics 192 (1) 2011: pp. 376-382.

22. Pyo, S.S., Lee, S.B., Lim, T.H., Song, R.H., Shin, D.R., Hyun, S.H., Yoo, Y.S. Characteristic of $\left(\mathrm{La}_{0 .} \mathrm{Sr}_{0.2}\right)_{0.98} \mathrm{MnO}_{3}$ Coating on Crofer22 APU Used as Metallic Interconnects for Solid Oxide Fuel Cell International Journal of Hydrogen Energy 36 (2) 2011: pp. 1868 - 1881.

23. Miguel-Pérez, V., Martínez-Amesti, A., Nó, M.L., Larrañaga, A., Arriortua, M.I. Oxide Scale Formation on Different Metallic Interconnects for Solid Oxide Fuel Cells Corrosion Science 60 2012: pp. 38-49.

24. Konysheva, E., Laatsch, J., Wessel, E., Tietz, F., Christiansen, N., Singheiser, L., Hilpert, K. Influence of Different Perovskite Interlayers on the Electrical Conductivity between $\mathrm{La}_{0.65} \mathrm{Sr}_{0.3} \mathrm{MnO}_{3}$ and Fe/Cr-based Steels Solid State Ionics 177 (9-10) 2006: pp. 923-930.

25. Park, H.R., Song, M.Y. Variation in the Oxidation Behavior of a Polished Ferritic Stainless Steel with Thermal Cycling Korean Journal of Metals and Materials 52 (6) 2014: pp. $421-427$.

26. Shim, S. Material Engineering for Next Generation Solid Oxide Fuel Cells. Ph D. Thesis, University of California Irvine, 2007.

27. Song, M.Y., Mumm, D.R., Song, J.Y., Yoon, S.D. Formation of Phases and Variation of Area Specific Resistance with Surface Roughness in Oxidized Crofer22 APU Korean Journal of Metals and Materials 52 (1) 2014: pp. $41-46$.

28. Mumm, D.R., Song, M.Y. Variation of Microstructure and Area Specific Resistance with Surface Roughness of a Ferritic Stainless Steel after Long-Term Oxygen Exposure Korean Journal of Metals and Materials 53 (4) 2015: pp. 270-276.

29. Yang, Z., Hardy, J.S., Walker, M.S., Xia, G.G., Simner, S.P., Stevenson, J.W. Structure and Conductivity of Thermally Grown Scales on Ferritic Fe-Cr-Mn Steel for SOFC Interconnect Application Journal of the Electrochemical Society 151 (11) 2004: pp. A1825-1831. http://dx.doi.org/10.1149/1.1797031 